\title{
1 Queer Visual Activism in South Africa
}

\author{
Tessa Lewin
}

\begin{abstract}
While the form of visual activism currently being developed in the United States and Western Europe is more commonly linked to street protests or activist campaigning and is often explicitly anti-capitalist, in South Africa visual activism has a different epistemological history and contemporary form. In the South African context, much visual activism is closely linked to the fine art market and its associated institutions. This is exemplified by the queer black South African photographer Zanele Muholi. Going beyond the body of work available on Muholi, however, this chapter uses the works of other South African artists, namely FAKA and Robert Hamblin, a fine art photographer, to explore visual activism and the way in which it complicates/broadens conventional conceptions of activism.
\end{abstract}

Keywords: Visual activism, queer, South Africa, FAKA, Robert Hamblin

\section{Introduction}

In this chapter I focus on queer visual activism in South Africa, which operates at the complex intersections of race, class and gender. ${ }^{1}$ The term 'visual activism' in South Africa is closely linked not only with the visual material that supports public protests, but with extensive artistic and photographic practices that can themselves be seen as forms of protest. I explore two contemporary examples of queer visual activism: the conceptual photography of Robert Hamblin and the performance work of FAKA and explore what it is in their work that constitutes activism in this

1 This chapter draws on my doctoral research for my thesis on Queer Visual Activism in Contemporary South Africa.

McGarry, A., I. Erhart, H. Eslen-Ziya, O.Jenzen, U. Korkut (eds), The Aesthetics of Global Protest: Visual Culture and Communication. Amsterdam: Amsterdam University Press, 2020 DOI 10.5117/9789463724913_CHO1 
specific sociocultural and sociopolitical context. ${ }^{2}$ The work of both FAKA and Hamblin is embedded in a politics of decolonization that recognizes how important visual aesthetics have been in the historical maintenance of racial capitalism (see Mirzoeff, this volume). Their work is best analysed through a lens of intersectionality that understands race, class, gender and sexuality as mutually co-constituting, interconnected systems of identification. Drawing on the work of black feminists, whose writing critiques the historical erasures of Western feminism, their work explicitly refuses to address sexuality in isolation from other forms of inequality (Crenshaw 1989; Mohanty 1988; Hill Collins and Blige 2016).

Robert Hamblin is a white, middle-class transgender man, whose project interseXion was produced in collaboration with The Sistaaz Hood, a black trans women sex worker support group. interseXion is the culmination of several years of their joint work on self-representation and identity. Very broadly, it can be seen as an advocacy project contributing to the lobbying for the decriminalization of sex work and as a pedagogical project that raises awareness around some of the socio-economic challenges faced by trans women sex workers in South Africa. Hamblin uses his images not just to generate income for himself, but also to mobilize resources for the members of The Sistaaz Hood. At its heart, though, it is also about using portrait photography to build relationships and to support psychosocial well-being.

FAKA is a queer black performance duo based in Johannesburg, made up of Desire Marea and Fela Gucci (the performance personas of Buyani Duma and Thato Ramaisa). FAKA's performance first emerged through a blog platform that the pair set up as an online networking and showcasing space for queer black South Africans. They perform in both clubs and galleries and continue to be involved in online fashion spaces. FAKA has recently been employed as brand ambassadors for Adidas and has worked with Versace, ${ }^{3}$ and the duo embrace this 'commodification of "blackness"' (hooks 2014: 152) as part of their broader project of challenging and remaking normative reality. I read this performative engagement with corporate capital through what Muñoz terms 'a mode of being in the world that is also inventing the world' (Muñoz 2009: 121). They are performing against the popular notion that one cannot be both queer and African (Ekine 2013) or male and

2 Post-apartheid South Africa remains one of the most racially divided and unequal societies in the world (Sulla and Zikhali 2018), with high levels of gender-based violence (Jewkes 2016), and gender and sexuality have emerged as significant sites of contest (Posel 2005).

3 Their track 'Uyang'khumbula' was chosen to launch Versace's 2019 Spring/Summer Fashion Show in Milan. 
feminine. They also view their visual activism as a pathway to the economic freedom denied to black South Africans prior to 1994 (Posel 2010; Southall 2007). The notion of economic freedom has taken on increased importance in South African public discourse in recent years as exemplified by the populist political party the EFF (Economic Freedom Fighters). ${ }^{4}$

\section{Visual Activism}

The term 'visual activism' has been used in a diverse range of contexts to describe a very broad range of activities from protest graffiti (Thomas 2018), political funerals (Thomas 2017), action research using photo elicitation (Wilson and Milne 2015) to fine art photography that allows the photographic subject some control over the framing of their portrait (see Hallas 2012). In the United States the first use of the term in academic literature I have identified was Cvetkovich's (2001: 285) writing on the activist groups Fierce Pussy, whose projects included wheat-pasting posters on the streets of New York (Burk 2015), and Lesbian Avengers, who staged performative protests (Rand 2013). Both groups were formed by members who were at the frontline of AIDS and queer activism throughout the 1980 s and early 1990s (Rand 2013: 122).

Currently, in the United States and Western Europe 'visual activism' is a term used to describe a form of activism based broadly in visual culture that has emerged following the financial and economic crash of 2008. These images are linked to political protest with examples including the burst of graffiti art that appeared in Cairo during the Arab Spring (Khatib 2013) or the now famous image of a ballerina on the bull statue that an Adbusters poster used to call for the occupation of Wall Street (McKee 2016a). These images often exceed or are situated outside of the formal institutions of the art world. This form of visual activism is more commonly linked to street protests or activist campaigning and is often explicitly linked to struggles against global capital and neoliberalism (Demos 2016; McKee 2016a, 2016b; Sholette 2017).

\section{Visual Activism in South Africa}

In post-apartheid South Africa, in contrast, much contemporary visual activism is closely linked to the fine art market and its associated institutions, 
and many visual activists see engagement with the institutions of the art world as a significant opportunity. This is exemplified by the black queer photographer Zanele Muholi, who has consistently described their own practice as 'visual activism' since their first solo exhibition at the Johannesburg Art Gallery in 2004 (Muholi 2009). Muholi's work has been exhibited extensively, both within South Africa and internationally, and their work points to a need to acknowledge the many different public spaces within which visual activism can be sited. Additionally, although Muholi's images are striking, and they themselves make significant epistemological and pedagogical interventions, much of what constitutes their activism is not apparent in these images. Through the activities surrounding the project that Muholi founded (inkanysio.org) and their training and mentoring of many other queer black South Africans, Muholi has used their visual practice to develop a community of black South African queers (Thomas 2013). What is significant is that their work, and that of many other visual activists in South Africa, uses the visual artefact (be it a performance or image) to build literal, metaphoric and relational value. Muholi's work builds on long history of activism both in the South African context and elsewhere that uses art as 'a constitutive force in the building of social movements' (Holmes 2012) 5 and fuses this with an astute awareness of how the art market and art institutions can amplify the message their work seeks to convey.

The term 'visual activism' appears to have emerged in South Africa at a similar time to its emergence elsewhere. South African visual theorist Kylie Thomas notes first hearing the term 'visual activism' in 2001 used by South African documentary photographer Gideon Mendel to describe his own HIV/AIDS activist work (Thomas 2017: 266). Mendel started calling himself not a documentary photographer where he was 'passively' witnessing subjects, but a visual activist since he had started actively trying to engage the participants of his photographs in their own representation. Mendel was working with Medicins sans Frontières (MSF) and the Treatment Action Campaign (TAC) on a series of photographs and films that were designed to support TAC's campaigning for the state provision of anti-retroviral drugs to HIV-positive people in South Africa (Hallas 2012).

South Africa has a rich history of activism at the intersection between art and politics. 'Visual activism' as a term is beginning to be retrospectively applied to this history of activism (Thomas 2017). Beginning with the 1950s many artists and photographers saw themselves as activists first and artists second while

5 Thompson's (2015) notion of art as creating 'structures of resonance' is a similarly useful concept here, as is Muñoz's (1999) discussion of 'queer worldmaking' in Disidenitifications. 
their work ranged from the photography documenting apartheid in the 1950 s to the art centres established in the 1970s that both supported individual artists and anti-apartheid activities. ${ }^{6}$ Through to the mid-1980s, with the heightening of the anti-apartheid movement, there emerged a significant international interest in South African visual production. Patricia Hayes suggests that after 1994 'the locus of the photograph shifted from the media to the gallery' (2011: 264). Certainly, both Hamblin and FAKA see the gallery as an important site for activist work as well as a space that allows them to access an international art market that supports their work (both literally and symbolically).

Following the Bantu Education Act of 1953, artists have worked in a context where black students were only taught subjects that would prepare them for unskilled service-based jobs in the labour market (Williamson 1989: 9). Moreover, these artists were continuously denied access to the galleries and museums, which were then the sole preserve of South Africa's white population (Lilla 2017). Both these factors cast a particular light on the historical importance of both FAKA and Sistaaz Hood's contemporary engagement with art institutions.

While visual activism during apartheid tended to focus on the antiapartheid struggle, after apartheid (1994) HIV/AIDS was seen by many as the 'new struggle' (Hayes 2011). Many of the photographers, who had been active in the anti-apartheid struggle, turned their attention to photographing HIV and AIDS (Wienand 2012: 177). There were numerous visual responses to the epidemic (Roberts 2001; Allen 2009; Thomas 2014) with evident close links between activist networks and artists.

The queer visual activist work of Robert Hamblin and FAKA builds on South Africa's legacy of anti-apartheid and HIV/AIDS activism. Their work exhibits two characteristics that reflect the historical lineage of their practice. The first is that they both exhibit a networked approach to visual practice that is strongly rooted within the social and look for multiple opportunities to build and sustain themselves through their work across activist, academic, media, entertainment, and art world platforms. The second is that both of them are consciously using money earned to further their activist work and hence are mostly pragmatic both in terms of making a living and enabling their activism as well as about the necessary collusion with global capital involved in the art market.

6 The activities of one such art centre (the Community Arts Project in Cape Town) is documented at http://www.sahistory.org.za/article/community-arts-project-cap, accessed 12.02.19, and its poster production in Berndt (2007). Seidman (2007) gives a broad overview of anti-apartheid poster production in South Africa. 
In the post-apartheid context, for FAKA, as black South Africans, engaging with the global market is seen not just a necessity, but as a right as well as an important post-apartheid freedom. This is because of the extent to which the apartheid government controlled what, how and when black South Africans were allowed to both acquire and spend money as their authority extended from the systematic forced removal of black South Africans from arable land to micro-management of what they were allowed to buy (Posel 2010). South Africa is still the most socio-economically unequal country in the world (Sulla and Zikhlai 2018). Although since the end of apartheid South Africa's upper classes are no longer exclusively white, the burden of poverty is still predominantly borne by its black African population (Durrheim et al. 2011: 17). In this context, for black South Africans, 'economic freedom', the right to earn money and control these earnings, is understood to be an expression of post-apartheid democracy (Posel 2010). This is a very different positionality to, for example, the France-based art collective LABOFII (Laboratory of Insurrectionary Imagination) that have pulled out of exhibitions sponsored by corporate capital as an anti-capitalist gesture (Demos 2016: 89). Hamblin and FAKA both employ strategies to engage and manipulate art institutions in a way that helps build and support both their political agendas and their communities.

\section{Relational Visual Activism}

interseXion, a collaboration between Robert Hamblin and The Sistaaz Hood fuses Hamblin's facilitation and advocacy skills from his NGO work with a fine art sensibility that has produced an extraordinarily beautiful and valuable body of art. This multidisciplinary approach that embeds the visual within a much broader social network characterizes the conception of this form of contemporary South African queer visual activism. interseXion grew out of a slow, in-depth, exploratory process during which Hamblin and The Sistaaz Hood jointly developed and negotiated their representation. Hereby, I try to give a detailed sense of this process, as an example of a form of visual activism, where the production of images contains and motivates a process of empowerment and movement building (through the production of the image) and pedagogy (through its display).

Hamblin's long-term collaborative project with The Sistaaz Hood, interseXion was exhibited at the Iziko National Gallery in Cape Town from March to July 2018. interseXion explores the complexities of sex work in South Africa. Hamblin contrasts his own trans identity as a privileged person in 
contrast with that of a homeless black trans women sex workers. interseXion comprises three series: The Sistaaz Hood Gallery (fig. 1.1), Diamond Town Girls and the installation InterseXion (fig. 1.2), which is made up of photography and video work. ${ }^{7}$ l look here at The Sistaaz Hood portraits and the video piece in InterseXion.

Hamblin started his professional career as a commercial photographer, before co-founding Gender DynamiX, a Cape Town-based NGO that supports transgender and gender non-conforming people. In 2012 Hamblin began to pursue a full-time career as a fine art photographer and thanks to his experience as a transgender advocate Hamblin helped to establish a support group for transgender women, SWEAT (Sex Workers Education and Advocacy Task Force), which supports the health and rights of sex workers. The Sistaaz Hood's first advocacy project was a joint photography project with Hamblin (named The Sistaaz Hood Gallery) exploring their representation. The development of the support group, and this body of work, is inseparable.

When The Sistaaz Hood learned that Hamblin was a photographer, they asked to be photographed. Over a period of several years, Hamblin and Sistaaz Hood, together, very consciously negotiated the terms of their engagement. Their photography project began as part commission part mutual exploration. As Hamblin recalls, one of the group instructed him:

You photograph rich women, and you do Photoshop on them, then they can just look amazing. You'll do the same with us. (Hamblin 2016)

Hamblin became interested in exploring in how transgender experiences illuminated social fault lines. Below, he reflects on this:

What happens when a male gives up his power? What happens when a poor person gives up masculine privilege. What happens to a black person within the patriarchy that transitions to being a woman? It's all there at this intersection. [...] A black transgender woman is all the intersections that we can look at where the patriarchy goes wrong. (Hamblin 2016)

Hamblin is articulating the fact that a black transgender sex worker exists at the intersection of numerous structural oppressions of race, class, gender, and sexuality. 


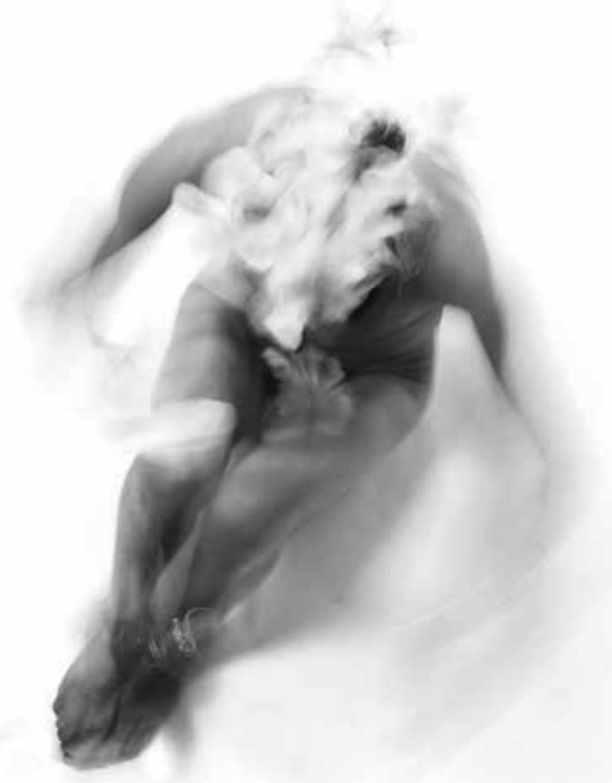

Figure 1.1. Sulaiga. From The Sistaaz Hood Gallery, 2016. Photo credit: Robert Hamblin.

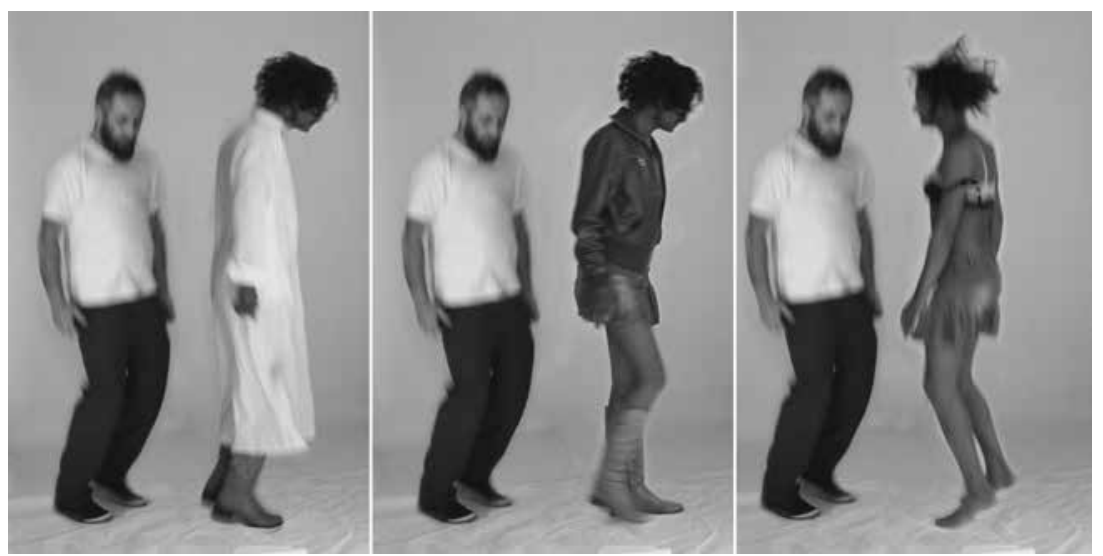

Figure 1.2. Stills from the video piece InterseXion, 2016. Photo credit: Robert Hamblin.

The form of Hamblin's photographs emerged through the mutual exploration of identity and representation that took place in his workshops with The Sistaaz Hood. Hamblin spoke about the process out of which The Sistaaz Hood portraits emerged: 
[A] beautiful thing that came for me from discussions around the project was about representation, you know, how do other artists look at us, how does the media look at us, we looked at all those things, very, it got more formalized and workshoppy. And then, how do you want me to look at you? What do you want me to see? They were all like 'well we're sex workers, so we want to be sexy, um, you have to pay us if you want to take off our clothes, we want to take our clothes off, because we are poor, we are never going to be able to alter our bodies, but people think we're crazy when we tell them that we're women, so we want to show that we don't have breasts, we're not ashamed of being poor, or that we're never going to be able to have breasts, we're not crazy, we know we don't have breasts. So, that was one of the elements, I had to show that, and then we spoke a lot about the performances they do when they are doing sex work. There's a lot of movement involved, so they have to perform, to obscure, to obscure, you know, their male bodies, so that's where the movement came from. (Hamblin 2016)

Hamblin's trademark long exposures which create a blurring of the image are here about obscuring the women's male-presenting bodies and showing the movement symbolic of the multiple performative moves they make. As in his other work, they are also about a refusal of fixed notions of identity. Hamblin describes revisiting the same themes within the group, and over several years, developing both a visual and verbal language with which to communicate. Through the collaborative process of crafting visual representations of themselves, Hamblin and The Sistaaz Hood go through a process of transformation in relation to their understanding both of themselves and of each other. Their visual project, and the work that both parties do in engaging with it, creates a space in which they both become active and learn from each other. Below, Hamblin talks about the importance of the collaboration being not so much about the image creation, but the mutual (self-)learning it facilitated:

So, it was an amazing collaboration that way, not a collaboration like we're making art together. A collaboration like in we're getting to know our identities here, and we are arming ourselves against a communal enemy. Ya, so that was the process of working with them. Very laborious. (Hamblin 2016)

It is the artefact that both arises out of this process, and also facilitates and contains the process. So, the activism is located at multiple points within 
and around the visual image and the interactions it both creates as well as by which it is created. Making this process of mutual (self-)learning through the artwork, which constitutes both a trace and distillation of the process, public is a brave act of pedagogy. It is also a further (public) assertion of both value and solidarity.

Hamblin's video piece InterseXion is about the bodies in which the intersections of class, gender and race collide. It reflects the maturity of the Hamblin/The Sistaaz Hood partnership. The video piece explores many of the themes of The Sistaaz's Hood portraits with much of same visual language but with the entry of Hamblin into the frame. Hamblin and (Leigh) Davids, one of The Sistaaz Hood, are juxtaposed on screen against a white floor and background in what reads as a dark-humoured nod to the hetero-iconography of wedding figurines. Davids (on the right of the screen) moves constantly, shifting between different identities, performatively required to be always on the move. Davids's movement is punctuated by the soundtrack in which she narrates her rejection from her community that led her living on the streets:

[W]ithin town you have poor trans people, living in communities out of the streets, and you have white rich trans people, and they live at home, and they live at home, home. I am here but able to tell them what it really is to be black, to live in poverty, and what it's like to not be accepted within society, due to the colour of your skin.

Although Hamblin and Davids share a trans gender identity, their race and class positions radically alter their experience. Davids's own story in the soundtrack is constantly, somewhat annoyingly, interrupted by her refrain: 'The colour of Robert's skin. Robert as a man, has an advantage, has an advantage.'

This serves the dual function of constantly emphasizing Robert's privilege both as a man and as white, and actively reinserting, or making dominant, Robert's presence even within Davids's own narrative, and thus re-inscribing both the mutual contingency of their positions and Robert's privilege.

Part of the discussions and negotiations around developing interseXion have also been about how best to navigate finances. Hamblin talks about trying to develop 'better ways' for artists to be, not just in terms of the content of his photographs, but also how he manages any income from the work. Here he explains how they have agreed to share any money that interseXion generates:

I paid them [The Sistaaz Hood members] for the shoot. A fee was negotiated [...] and then I gave them commission on sales on the first edition of 
the print. Anyway - so that. And then, except for that, they are my 50 per cent partners. So, after all the costs have been paid, and the commissions have been paid, then the profit on the work, I get half and the group gets half. ${ }^{8}$ (Hamblin 2016)

This financial arrangement reflects Hamblin's acknowledgement of the collaborative nature of the work. The work toured in 2017 and Hamblin travelled with members of The Sistaaz Hood group. It is partly the extent to which Hamblin acknowledges the collaborative debt that makes this work both queer and activist.

Tragically, Leigh Davids died on 27 February 2019, two weeks before her $40^{\text {th }}$ birthday. Her death has transformed her work into an archive of her struggles to be seen and heard, and her desire for solidarity (see McGarry et al., this volume). For Davids, this work had very real political stakes. interseXion was not just part of an advocacy campaign to decriminalize sex work, and it was not just a mutual exploration of trans-identity and representation. It was also about using visual production to create literal and symbolic capital, both for those directly involved in the project, and for future generations.

\section{FAKA's Subversions}

The following section examines the performance practice of the duo FAKA, whose practice moves between gallery spaces, fashion blogs, and festivals. FAKA talk about themselves not just as a duo, but as a 'queer movement' (Duma 2015). They envisage themselves as mothers of the 'House of FAKA', after the New York ball culture documented in Paris Is Burning (Livingston 1990), using their practice to create a safe space for a community of fellow queer black South Africans. In the section that follows, I draw on an interview that I conducted in 2015 in Johannesburg with Buyani Duma (aka Desire Marea), one half of the FAKA duo.

For FAKA, being visible is being activist and they exploit commodification to augment their visibility (Duma 2015). They use self-actualization through fashion and consumerism to remake normative reality and carefully crafted spectacles to create contemporary indigenous queer rituals. There have been three broad strands to their work so far: gallery-based performance pieces,

8 Hamblin and The Sistaaz Hood have revised this financial agreement since this interview, and now all profits from this work go towards The Sistaaz Hood project. 


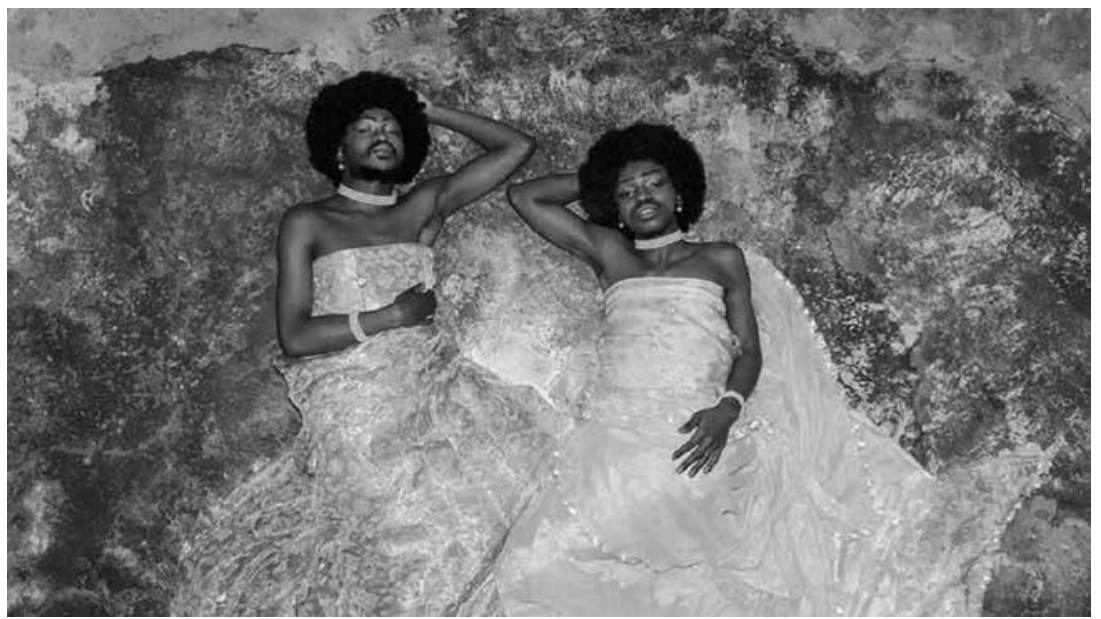

Figure 1.3. FAKA, 2016. Photo credit: Nick Widmer.

music videos, and heavily stylized fashion (self-)portraits. Their aesthetic sense is extremely powerful and unusual, partly in the way that they blend contemporary and traditional visual elements and partly in their embrace of the erotic as well as of their femininity. FAKA means 'to penetrate', but also 'to contribute to', so even within their name there is surprising mixture of irreverence and social responsibility.

South Africa is famous for its regional exceptionalism in Africa marked both by its 1996 constitution, which explicitly outlaws discrimination based on sexuality or gender, and the existence of gay marriage. ${ }^{9}$ However, despite this legal inclusion, there have been numerous cases of violent homophobic murder, 'signifying the continued social exclusion of those at the sexual margins' (Judge 2015: iii). Much queer visual activist work in South Africa has concentrated on the documentation of hate crimes and either supporting or challenging the criminal justice system in an attempt to better support the victims of hate crimes..$^{10}$ FAKA's artistic production on the surface is the antithesis of this kind of work. It is much more concerned with celebrating life, and fabulousness, than documenting death. Yet, it too is motivated by a desire to challenge both damaging gender norms and homophobia. FAKA's decision to be artists was based a belief 'that culture is a higher governing body than law when it

9 South Africa became the fifth country in the world to legalize marriage of same-sex couples in 2006. The debates around this reform, and the journey taken towards its institution are celebrated, documented, and analysed in Judge et al. (2008)

10 See, for example, the work done by Zanele Muholi with Inkanyiso, and by Iranti.org 
comes to power over bodies, ${ }^{\prime 1}$ an opinion echoed by Steyn and Van Zyl, who suggest that without challenging the gendered nature of social institutions, gender-based violence will persist, regardless of how well the criminal justice system works (2009: 12). In challenging normative gender constructions by unapologetically embracing their femininity and the social conservatism around sexuality (by being overtly sexual), FAKA hope to challenge both gender-based violence ${ }^{12}$ and homophobia. Here Duma explains this as follows:

we represent our generation, and our generation needs different things. Like, it's a whole different narrative now. It's more about issues of representation, and yes, the hate crimes are still there, but we sort of try to get to the root of things, because we wouldn't feel like there would be so much homophobia if sexuality wasn't so like frowned upon in our society. Because anything that even hints at sexuality is like completely expunged, and that's why AIDS, or HIV, was stigmatized for such a long time. (Duma 2015)

FAKA's performance piece Wait Lorraine (2015) is about refusing the stigma attached to sexuality. ${ }^{13}$ Wait Lorraine is partly an assertion of pride, but it is also an emphatic countering of the argument that homosexuality is un-African; an argument that structures much homophobia in South Africa (Ekine 2013). FAKA's work is both definitively queer, and definitively (South) African.

FAKA consciously position themselves as role models offering guidance to younger black South African queers. Borrowing from Pepper Labeija, ${ }^{14}$ Duma introduces himself as 'Desire Marea - legendary half mother of the house of FAKA'. The younger artists they profile on their website ${ }^{15}$ they refer to as 'Top Upcoming Legendary Children', and 'The House of FAKA', is 'a counterinstitution meant to shelter everybody, who is alienated by mainstream culture' (Duma 2015).

FAKA's desire to be famous is very much imbricated in their desire to model what Muñoz (2009) calls a 'critical utopia', and FAKA a 'reimagined

11 See Duma's talk at Creative Mornings Johannesburg, June 2016, https://www.youtube.com/ watch? $\mathrm{v}=\mathrm{kFkgN}$ PGdMM, accessed 12.02.19.

12 South Africa has extraordinarily high levels of gender-based violence, with more rapes committed per capita than any other country in the world (Anderson 2000: 789). Gqola argues that rape works to keep patriarchy intact (2015:21) and that it is a national culture, not just a behaviour attributable to a small minority of men (ibid.: 178).

13 https://www.youtube.com/watch?time_continue=181\&v=uzJyF1QIyrA.

14 A central figure from the New York ball scene of the 1980 .

15 www.siyakaka.com. 
existence for black queer people'. Duma, explaining the importance of the gay celebrity Somizi Mhlongo, equates visibility with activism:

[J] ust by being visible, I feel that that in itself is activism. [...] [T] here are so many people. And some are not actually fine artists, but it's queer visual activism. There's a South African called Somizi Mhlongo - he acted in Sarafina the musical, then in the 8os, he was the first black man I knew to be publicly homosexual (when I was a kid) and that was unheard of, and he did it with such grace, and he stayed true to himself. And he's been successful for so many years, he's been a role model. [...] [I]f Somizi didn't exist, we'd actually be in a different place, like in terms of society. Maybe my grandparents wouldn't be as exposed to knowing what a homosexual man is, that a homosexual man can be a talented performer on television. He can be a person who loves his mother, because he's been public about that as well, and he has a daughter as well, and the complexity is so humanized. (Duma 2015)

So, for Duma, Somizi's presence on national television provides much needed proof not only that queer people can exist, but that they can be valued (socially and economically) and that they are capable of having the kinds of loving family relationships that his grandparents regard as important. Somizi's public visibility both facilitates (in relation to his family) and affirms (in relation to himself) Duma's own queerness.

Many of the people that Duma cited as his queer activist heroes are celebrities or public figures. To him, they are activist in the sense that they are 'out', and therefore actively, daily, challenging dominant social norms, that talk of queerness as 'un-African' (Hoad 2007: xi; Gunkel 2010: 25), that require men (and women) to be gendered in a particular way, and that violently police the boundaries of heteronormativity. Currier (2012) and Tucker (2009) have both shown how queer South Africans strategically shift between visibility and invisibility to protect themselves. Duma's respect for queer black South Africans, who are unequivocally, permanently 'out' is partly about the fact that they are allowing the general public access to queer representations.

FAKA sees the art world as just one of the platforms that will help them access bigger and more diverse audiences in the long term:

Right now, our audience is not the audience we want, because our audience is mostly at art galleries, and it's a very concentrated niche audience. We so badly want to have mainstream impact. [...] [T] he art world is slowly becoming more open [...] but I guess the art world is also a business and 
they need to make money. So, it's sort of something you have to do on your own, independently as an artist, like put up your own structures that actually reflect that ideology of accessible art [...] with the help of the art world. We don't want to limit ourselves to fine art or anything like that. We want to be FAKA on television, we want to bring the truth there. We want to be FAKA in magazines. (Duma 2015)

Since this interview, FAKA's ambitions have in many ways been realized. In 2016, they were appointed as 'brand ambassadors' for Adidas. Even given the elision of culture and consumerism in contemporary South Africa (Nuttall 2011), it seems counterintuitive to be celebrating this as a victory for queer visual activism. However, the members of FAKA argues that they are consciously using the Adidas brand to promote themselves, and to subvert mainstream or normative representations. In an interview with the Mail and Guardian, a weekly newspaper in South Africa, Duma talks about using capitalism as a resource:

Capitalism gives us access to all the artefacts that can have a different meaning when subverted. Also, when you are at the forefront of a cultural phenomenon in a time when culture is gaining a lot of economic power, you will find people trying to commodify you. It is weird for us because the thing they would commodify is the very idea of our bodies, our identities basically. (Quoted in Bongela 2016)

Although Duma expresses some discomfort with being commodified by a brand, he sees it as inevitable, and goes on to talk about the fact that this is strategically useful in furthering not just their political project but their own brand. Adidas may be using FAKA to stay relevant, but FAKA is using them back, and is fairly confident that it is their own narrative that will win out as more interesting. Here Duma talks about the inevitability of collaboration between consumer brands and what Bongela (the Mail and Guardian journalist interviewing Duma) calls 'self-made internet stars':

You know, it is an inescapable reality. We grew up in a very consumerist black society and in many cases the choices concerning brands were very irrational, in a sense that we believed that the brands did something to us that made us 'better' or 'okay' or 'less black and poor'. I think that was a reality a lot of black youth were trying to escape: the fact of poverty. We believed brands had the power to change that narrative. We find it interesting now, to see brands scrambling for relevant black artists to 
change the narrative of the cultural bankruptcy of their brands. The Adidas campaign for us was more a story of representation and in a way, we had to have faith that that story would be more potent. (Quoted in Bongela 2016)

In 2018, FAKA's music track 'Uyang'Khumbula' was chosen by designer fashion label Versace to accompany the launch of their spring/summer 2019 collection. This particular success has great significance for FAKA because fashion and self-fashioning have been central to their self-actualization. Duma says that one of the things that brought himself and Ramaisa together was the mutual understanding that they 'didn't have the money to have certain things that make you matter these days'. Through performing FAKA, they are laying claim to that which has been previously denied to them. In the particular context of post-apartheid South Africa, their self-actualization through fashion and consumerism becomes analogous not only with a post-apartheid black freedom ${ }^{16}$ but also with a utopian enacting of their gender and sexuality that moves FAKA, and their audience beyond the present. Exemplifying the queerness that Muñoz characterizes in Cruising Utopia, as 'a structuring and educated mode of desiring that allow us to see and feel beyond the quagmire of the present' (2009:1).

\section{From Self-styling to Solidarity}

The literature on visual activism suggests a false dichotomy between two distinct forms - one emerging in Western Europe and America post the financial and economic crash of 2008, situated outside of the formal institutions of the art world, and linked to street protests, or activist campaigning, and often explicitly anti-capitalist (Demos 2016; McKee 2016a, 2016b; Sholette 2017). The other emerging in post-apartheid South Africa and closely linked to the fine art market and its associated institutions. Because much of the literature on visual activism is written by scholars from visual studies or art history, it tends to focus its analysis on the visual artefact rather than the practices that surround the production of this work, thus exacerbating the distinction between these two forms. This binary division is further emphasized by analysis that positions 'protest art' as authentic, and art based in institutions as inauthentic - because of its complicity with global capital (Demos 2016). The examples of Hamblin and FAKA's practice explored in this chapter both complicate and broaden existing understandings of visual activism and allow us to see similarities 
between two allegedly distinct forms of activism, both of which use art as 'a constitutive force in the building of social movements' (Holmes 2012). Like the exhibition discussed in Eğrikavuk's work (this volume) both artists recognize and utilize the convening power of their artistic practice. Their work creates a space of resistance which brings people together (Eğrikavuk, this volume).

Tulke's framing of political street art in Athens (this volume) as an 'aesthetics of crisis' also resonates with this work. Hamblin and FAKA's practice are driven by the representational marginalization of queer intersectionality in South Africa. Their work is partly a 'space for emotional processing' (Tulke, this volume) but in centring and valuing non-hegemonic identities they are also weaving 'a sense of political potentiality into the very fabric of everyday life' (ibid.).

Hamblin and FAKA are opportunistic in their use of available resources to support and amplify their work. Through the process of their visual practice, they create literal and symbolic capital which they use to build and support communities. Although there are clearly multiple tensions and contradictions raised by a model of activism that embraces an imbrication with art markets and consumer brands, there is no doubt that this work constitutes a form of protest. What we learn from these two examples of queer visual activism is that visual activism can be multisited and does not always present in an 'obvious' form. The relationship between activists and capital is often a complex and often contradictory one. Where, on the one hand, activism is seen as a route to economic freedom, on the other, refusing to engage with corporate capital may be seen not only as a privileged position but also as counterproductive to the visibility on which activism depends.

Through my reading of Hamblin and FAKA's work, I demonstrate how they use visual forms to document experiences that would otherwise be invisible in the public sphere, represent themselves as they wish to be seen, and expand the boundaries of gendered identities. Crucially, in both examples I have traced their move in their artistic practice from an individual project of self-styling to a solidarity with others that eventually constitutes a form of movement building.

\section{References}

Allen, Rika. 2009. 'Art Activism in South Africa and the Ethics of Representation in a Time of AIDS', Critical Arts 23(3): 396-415.

Anderson, Michelle J. 2000. 'Rape in South Africa', Georgetown Journal of Gender and the Law 1: 789-821. 
Berndt, John. 2007. From Weapon to Ornament: The CAP Media Project Posters (1982 to 1994). Cape Town: Arts and Media Access Centre.

Bongela, Milisuthando. 2016. 'FAKA: Making Living Performance Art That Flips the Script on Gender Norms'. Mail and Guardian (Johannesburg), 29 September.

Burk, Tara Jean-Kelly. 2015. Let the Record Show: Mapping Queer Art and Activism in New York City, 1986-1995. PhD thesis, CUNY Graduate Center.

Crenshaw, Kimberlé W. 1989. 'Demarginalizing the Intersection of Race and Sex: A Black Feminist Critique of Antidiscrimination Doctrine, Feminist Theory, and Antiracist Politics', University of Chicago Legal Forum 139: 139-167.

Currier, Ashley. 2012. Out in Africa: LGBT Organizing in Namibia and South Africa. Minneapolis: University of Minnesota Press.

Cvetkovich, Ann. 2001. 'Fierce Pussies and Lesbian Avengers: Dyke Activism Meets Celebrity Culture', in Feminist Consequences, ed. Elizabeth Bronfen and Misha Kavka, 283-318. New York, Columbia University Press.

Demos, T.J. 2016. 'Between Rebel Creativity and Reification: For and Against Visual Activism', Journal of Visual Culture 15(1): 85-102.

Duma, Buyani. 2015. Interview, Johannesburg, November.

Durrheim, Kevin, Xoliswa Mtose, and Lyndsay Brown. 2011. Race Trouble: Race, Identity and Inequality in Post-Apartheid South Africa. Natal: University of KwaZulu-Natal Press

Ekine, Sokari. 2013. 'Contesting Narratives of Queer Africa', in Queer African Reader, ed. Sokari Ekine and Hakima Abbas, 78-91. Dakar: Pambazuka Press.

Gqola, Pumla. 2015. Rape: A South African Nightmare. Johannesburg: Jacana.

Gunkel, Henriette. 2010. The Cultural Politics of Female Sexuality in South Africa. London, Routledge.

Hallas, Roger. 2012. 'Photojournalism, NGOs, and the New Media Ecology', in Sensible Politics: The Visual Culture of Nongovernmental Activism, ed. Meg McLagan and Yates McKee, 95-116. New York: Zone Books.

Hamblin, Robert. 2016. Interview, Cape Town, November.

Hayes, Patricia. 2011. 'The Form of the Norm: Shades of Gender in South African Photography of the 1980s', Social Dynamics 37(2): 263-277.

Hill Collins, Patricia, and Silma Bilge. 2016. Intersectionality. Cambridge: Polity Press.

Hoad, Neville. 2007. African Intimacies: Race, Homosexuality and Globalization. Minneapolis: University of Minnesota Press.

Holder, Alex. 2017. 'Sex Doesn't Sell Any More, Activism Does: And Don't the Big Brands Know It'. The Guardian, 3 February.

Holmes, Brian. 2012. 'Eventwork: The Fourfold Matrix of Contemporary Social Movements', in Living as Form: Socially Engaged Art from 1991-2011, ed. Nato Thompson, 72-93. New York, Creative Time. 
hooks, bell. 2014. 'Is Paris Burning?', in Black Looks: Race and Representation, 145-156. New York: Routledge.

Jewkes, Rachel. 2016. Gender-Based Violence (GBV) in South Africa: A BriefReview. Pretoria: CSVR.

Judge, Melanie. 2015. Violence against Lesbians and (Im)possibilities for Identity and Politics. PhD thesis, University of the Western Cape.

Judge, Melanie, Anthony Manion, and Shaun De Waal. 2008. To Have and to Hold: The Making of Same-sex Marriage in South Africa. Johannesburg: Jacana.

Khatib, Lina. 2013. Image Politics in the Middle East: The Role of the Visual in Political Struggle. London: I.B. Tauris.

Lilla, Qanita. 2017. Setting Art Apart:Inside and Outside the South African National Gallery (1895-2016). PhD thesis, Stellenbosch University.

Livingston, Jennie. 1990. Paris Is Burning [documentary film].

McKee, Yates. 2016a. 'Occupy and the End of Socially Engaged Art', eflux 72.

McKee, Yates. 2016b. Strike Art: Contemporary Art and the Post-Occupy Condition. London: Verso Books.

Mohanty, C.T. 1988. 'Under Western Eyes: Feminist Scholarship and Colonial Discourses', Feminist Review 30: 61-88.

Muholi, Zanele. 2009. Mapping Our Histories: A Visual History of Black Lesbians in Post-Apartheid South Africa, MA thesis, Ryerson University.

Muñoz, José Esteban. 1999. Disidentifications: Queers of Color and the Performance of Politics. Minneapolis: University of Minnesota Press.

Muñoz, José Esteban. 2009. Cruising Utopia: The Then and There of Queer Futurity. New York: New York University Press.

Nuttall, Sarah. 2011. 'Self-Styling', in Global Visual Cultures: An Anthology, ed. Zoya Kocur, 270-292. Chichester: Wiley-Blackwell.

Posel, Deborah. 2005. 'Sex, Death and the Fate of the Nation: Reflection of the Politicization of Sexuality in Post-Apartheid South Africa', Africa 75(2): 125-153. Posel, Deborah. 2010. 'Races to Consume: Revisiting South Africa's History of Race, Consumption and the Struggle for Freedom', Ethnic and Racial Studies 33(10): 157-175. Rand, Erin J. 2013. 'An Appetite for Activism: The Lesbian Avengers and the Queer Politics of Visibility', Women's Studies in Communication 36(2): 121-141.

Roberts, Allen. 2001. "Break the Silence": Art and HIV/AIDS in KwaZulu-Natal', African Arts 34(1): 36-49.

Seidman, Judy. 2007. Red on Black: The Story of the South African Poster Movement. Johannesburg: STE Publishers.

Sholette, Greg. 2017. Delirium and Resistance:Activist Art and the Crisis of Capitalism. London: Pluto Press.

Simelela, N.P., and W.D.F. Venter. 2014. 'A Brief History of South Africa's Response to AIDS', South African Medical Journal 104(3): 249-251. 
Southall, Roger. 2007. 'Ten Propositions about Black Economic Empowerment in South Africa', Review of African Political Economy 34(111): 67-84.

Steyn, Melissa, and Mikki van Zyl, eds. 2009. The Prize and the Price: Shaping Sexualities in South Africa. Pretoria: HSRC Press.

Sulla, Victor, and Precious Zikhali. 2018. Overcoming Poverty and Inequality in South Africa: An Assessment of Drivers, Constraints and Opportunities. Washington, DC: International Bank for Reconstruction and Development/The World Bank. Thomas, Kylie. 2013. 'Digital Visual Activism: A Profile of Inkanyiso', Feminist Africa 18: 79-81

Thomas, Kylie. 2014. Impossible Mourning: HIV/AIDS and Visuality after Apartheid. Johannesburg: Wits University Press.

Thomas, Kylie. 2017. 'Rage against the State: Political Funerals and Queer Visual Activism in Post-Apartheid South Africa', in Public Art in South Africa: Bronze Warriors and Plastic Presidents, ed. Kim Miller and Brenda Schmahmann, 265-281. Bloomington: Indiana University Press.

Thomas, Kylie. 2018. "Remember Marikana”: Violence and Visual Activism in Post-Apartheid South Africa', ASAP/Journal 3(2): 401-422.

Thompson, Nato. 2015. Seeing Power: Art and Activism in the $27^{\text {st }}$ Century. London: Melville House.

Tucker, Andrew. 2009. Queer Visibilities: Space, Identity and Interaction in Cape Town. Oxford: Wiley-Blackwell.

Wienand, Annabelle. 2012. 'Portraits, Publics and Politics: Gisèle Wulfsohn's Photographs of HIV/AIDS, 1987-2007', Kronos 38: 177-203.

Williamson, Sue. 1989. Resistance Art in South Africa. Cape Town: David Philip. Wilson, Sarah, and Elisabeth-Jane Milne. 2015. 'Visual Activism and Social Justice: Using Visual Methods to Make Young People's Complex Lives Visible across "Public" and "Private" Spaces', Current Sociology 64(1):140-156.

\section{About the Author}

Tessa Lewin is a doctoral candidate at the University of Brighton, where she is writing her thesis on queer visual activism in contemporary South Africa. She is also a Research Fellow at the Institute of Development Studies, where her work involves creative, visual and participatory research, teaching and communication. 